\title{
17 The current status of gorillas and threats to their existence at the beginning of a new millennium
}

ANDREW J. PLUMPTRE, ALASTAIR M CNEILAGE, JEFFERSON

S. HALL, AND ELIZABETH A. WILLIAMSON

\section{The status of gorilla populations}

Gorilla numbers across Africa have declined dramatically over the last century. Some of the earliest conservation efforts on the continent were aimed at protecting mountain gorillas, but destruction of habitat, hunting, and human disturbance have all contributed to the reduction of gorilla populations. All gorilla subspecies are classified as "Endangered" according to the International Union for Conservation of Nature (IUCN) criteria (Oates, 1996; IUCN, 2000). However, in recent years, innovative new conservation ideas have been applied, which have shown some success in slowing the decline, and have even allowed some populations to start to recover. In this chapter, we review the current threats to gorilla populations, and outline some of the strategies that may hold the key to their survival in the twenty-first century.

Gorillas are found in the forests of central Africa, from Nigeria in the west to Rwanda and Uganda in the east, with most animals occurring in the Congo Basin (Cameroon to eastern Democratic Republic of Congo) (DRC) (Fig. 17.1). Until recently there were thought to be three subspecies of gorilla, the mountain gorilla (Gorilla gorilla beringei), the Grauer's gorilla (G. gorilla graueri) and the western lowland gorilla (G. gorilla gorilla). Recent taxonomic research is now suggesting that there are more subspecies (Sarmiento et al., 1996; Oates et al., this volume) and possibly that western and eastern populations should be given separate specific status, G. gorilla and G. beringei, on the basis of genetic and morphological differences (Groves, 2001, this volume)

Where gorillas occur they are generally found at densities ranging between 0.1 and 2.5 individuals $/ \mathrm{km}^{2}$, occasionally as high as 10.6 locally. They tend to occur at their highest densities in secondary forest (Carroll, 1988; Fay, 1989, 1997; Hall et al., 1998a). Extrapolating from where gorillas have been surveyed to their known range of occurrence allows us to estimate the sizes of the various populations (Table 17.1). If we use the taxonomic classification that 


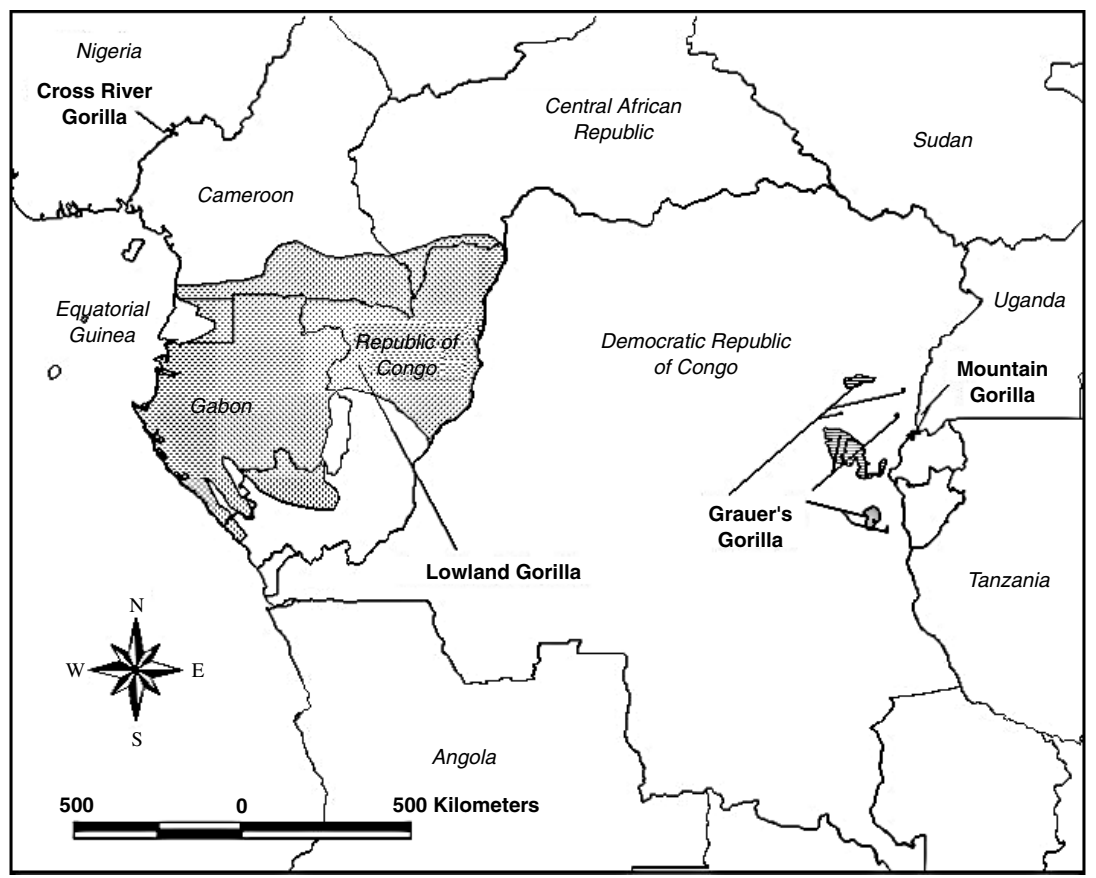

Fig. 17.1. Distribution of gorillas across Africa.

existed from the 1980s until the mid 1990s, then population sizes are as follows: G. g. gorilla (population of about 110000 ), G. g. graueri (population of about 17000 ), and G. g. beringei (population of around 650-700). If the gorillas in Bwindi-Impenetrable National Park in southwest Uganda are different from the mountain gorillas in the Virungas (Sarmiento et al., 1996) then there would only be around 360-395 mountain gorillas (J. Kalpers et al., unpublished data). Similarly, if the gorillas found on the Nigeria-Cameroon border around the Cross River are accepted as a new subspecies, G. $g$. diehli, then these would become the rarest subspecies of gorilla with only about 150-200 individuals (Sarmiento and Oates, 2000; Oates et al., this volume).

Whether we accept these further divisions of gorilla populations or not, all gorilla populations are threatened throughout their range, primarily by human activities. As human populations increase in Africa the available habitat for gorillas is decreasing and gorillas are coming into contact with humans much more than they used to. Each of the subspecies is threatened by different factors that result from increasing human populations, and all gorilla populations are considered under IUCN criteria as "Endangered" (Harcourt, 1996). 
Table 17.1. The densities of gorillas at various sites in Africa and approximations of population size for each country

\begin{tabular}{|c|c|c|c|c|}
\hline Country & Region & $\begin{array}{l}\text { Density } \\
\text { (individuals/km) }\end{array}$ & $\begin{array}{l}\text { Population } \\
\text { size }^{a}\end{array}$ & Reference \\
\hline \multicolumn{5}{|l|}{ Cross River gorilla } \\
\hline Nigeria/Cameroon & Cross River area & 0.8 & $150-200$ & $\begin{array}{l}\text { Harcourt et al., 1989; Oates } \\
\text { et al., this volume }\end{array}$ \\
\hline \multicolumn{5}{|l|}{ Lowland gorilla } \\
\hline \multirow[t]{5}{*}{ Cameroon } & Whole country & & 12500 & Harcourt, 1996 \\
\hline & Boumba Bek & 1.6 & & Stromayer and Ekobo, 1991 \\
\hline & Dja Reserve & 1.7 & & $\begin{array}{l}\text { Williamson and Usongo, } \\
1995\end{array}$ \\
\hline & Lac Lobéké & 2.5 & & Fay, 1997 \\
\hline & Mongokele & 1.2 & & Fay, 1997 \\
\hline Equatorial Guinea & & & 3000 & Jones and Sabater Pi, 1971 \\
\hline \multirow[t]{2}{*}{ Gabon } & & 0.2 & 43000 & Tutin and Fernandez, 1984 \\
\hline & Lopé Reserve & 0.5 & & White, 1992 \\
\hline \multirow{9}{*}{$\begin{array}{l}\text { Democratic Republic of } \\
\text { Congo }\end{array}$} & & 0.4 & 44000 & Harcourt, 1996; Fay, 1997 \\
\hline & Odzala & 10.0 & & Fay, 1997 \\
\hline & Mboukou & 1.2 & & Fay, 1997 \\
\hline & Motaba & 0.1 & & Fay, 1997 \\
\hline & Ndoki & 0.2 & & Fay, 1997 \\
\hline & Mbomo & 0.6 & & Fay, 1997 \\
\hline & Garabinzam & 0.5 & & Fay, 1997 \\
\hline & Northern Congo & 0.4 & & Fay, 1997 \\
\hline & Southern Congo & 0.05 & & Fay, 1997 \\
\hline \multirow[t]{2}{*}{ Central African Republic } & Sangha region & $0.8-1.5$ & 9000 & Carroll, 1988 \\
\hline & Secondary forest & 10.6 & & Carroll, 1988; Fay, 1997 \\
\hline Angola & NW Angola & very low to zero & 0 & Fay, 1997 \\
\hline $\begin{array}{l}\text { Democratic Republic of } \\
\text { Congo }\end{array}$ & $\begin{array}{l}\text { NW Democratic } \\
\text { Republic of Congo }\end{array}$ & very low to zero & 0 & Fay, 1997 \\
\hline \multicolumn{5}{|l|}{ Grauer's gorilla } \\
\hline \multicolumn{5}{|l|}{$\begin{array}{l}\text { Democratic Republic of } \\
\text { Congo }\end{array}$} \\
\hline & $\begin{array}{l}\text { Kahuzi-Biega } \\
\text { National Park }\end{array}$ & 1.26 & 14900 & Hall et al., $1998 b$ \\
\hline & Maiko National Park & 0.25 & 859 & $\begin{array}{l}\text { Hart and Hall, 1996; Hall } \\
\quad \text { et al., } 1998 b\end{array}$ \\
\hline & Itombwe & & 1155 & Hall et al., $1998 b$ \\
\hline & Mt. Tshiaberimu & & 16 & $\begin{array}{l}\text { Butynski and Sarmiento, } \\
\text { 1995; Hall et al., 1998b }\end{array}$ \\
\hline & $\cdots \cdots$ & & n & * ' ing8; Hall \\
\hline \multicolumn{5}{|l|}{ Mountain gorilla } \\
\hline $\begin{array}{l}\text { Rwanda, Democratic } \\
\text { Republic of Congo, Uganda }\end{array}$ & Virungas & 0.9 & $360-395$ & $\begin{array}{l}\text { J. Kalpers et al., unpublished } \\
\text { data }\end{array}$ \\
\hline Uganda & Bwindi & 0.9 & 300 & McNeilage et al., 1998 \\
\hline
\end{tabular}

${ }^{a}$ The populations have been given for the three subspecies (Groves, 1967) because there are fewest of these. 
The major threats to gorillas can be categorized as: (1) habitat loss, modification, or fragmentation; (2) hunting or poaching; (3) disease transmission from humans; and (4) war or political unrest. We first review these threats and then outline conservation initiatives underway to address them.

\section{Threats to gorilla populations}

\section{Habitat loss or modification}

Habitat loss due to agriculture or modification, through logging, fuel wood and nontimber forest product collection, and grazing domestic animals, is undoubtedly one of the greatest long-term threats to gorillas. Gorillas are dependent on forest habitat that, once converted to agriculture, rarely reverts back to natural vegetation unless it can be left for hundreds of years. Even where forest is not destroyed, it may be effectively lost as gorilla habitat if disturbance is severe enough.

The bulk of the western populations lives outside protected areas. The western gorillas are consequently most at threat from loss or modification of habitat. In the Congo Basin, average deforestation rates are about $0.5 \%$ per year (World Resources Institute, 2000a). Where human density is high, forest clearance is also high (Barnes, 1990; Harcourt, 1996), and therefore it is not surprising that gorilla populations are healthiest in the most remote areas of the Congo Basin such as northern Congo and Gabon (Table 17.1). The western populations are also most affected by selective logging. The impacts of logging vary depending on whether hunting accompanies logging operations. Logging concessions now cover $76 \%$ of the forest in Cameroon (World Resources Institute, 2000b) and 56\% of the forest in Gabon (World Resources Institute, 2000a). Similar percentages occur for the Democratic Republic of Congo (J. Brunner, personal communication) and the Central African Republic (50-75\%). When civil war in the DRC ends it is very probable that logging companies will quickly move into this country as well. If there is no hunting of gorillas within the concessions, gorillas probably can coexist with logging because they tend to favor areas of secondary vegetation where herbaceous food plants can be found (Harcourt, 1981; White, 1992, 1994; Fay, 1997). No study has directly compared gorilla populations before and after logging in a specific site, but significant gorilla populations have been found in previously logged forest comparable with densities in unlogged forest (White, 1994). However, where hunting does occur, large-bodied and slow-reproducing species such as gorillas are usually eliminated completely (Lahm, 1994; Wilkie and Carpenter, 1999a), and hunting does go on virtually everywhere that logging is carried out. 
In eastern DRC, George Schaller surveyed gorilla populations in the early 1960s (Schaller, 1963), which have since been lost following forest clearance (Hall et al., 1998a). With the current instability in DRC, we have no concrete figures, but the rate of habitat loss for Grauer's gorillas is probably the highest of any subspecies.

In 1959, Schaller carried out the first extensive research on any of the gorilla subspecies in the wild. At that time, he considered habitat loss to be the greatest danger to the survival of the mountain gorillas (Schaller, 1963). Following this prediction, about $54 \%$ of the Rwandan part of the Virungas was taken for an agricultural project between 1967 and 1970 (Weber, 1987), and the mountain gorilla population dropped from an estimated 400-500 to 252 animals (Harcourt and Fossey, 1981; Weber and Vedder, 1983). However, in recent years, habitat loss has been close to zero, although war and instabilities in the Virungas has caused some disturbance to habitat.

\section{Hunting or poaching}

The killing of gorillas can be direct or indirect depending on whether they are specifically targeted or are unintentionally trapped by snares. The major reasons for intentional killing of gorillas are: (1) meat, (2) capture of animals for collections, and (3) body parts for trophies. The extent of hunting of gorillas for meat varies across their range according to local traditions and taboos and the effectiveness of protection measures. Infant gorillas from all subspecies have been captured for sale or attempted sale to zoological or private collections. During the process of capture, adult males and females are often killed whilst trying to protect their infants. For every infant that reaches a zoo, many other animals die. For example, in 1968-69, 18 gorillas were killed in attempts to capture gorilla infants (Fossey, 1983). Many of the infants sold to collections from the western gorilla populations may be caught when adults are hunted for meat and hence the sale of infants may at times be a byproduct of the bushmeat trade.

Gorillas were hunted directly for trophies (skulls, hands, feet, and skins) until quite recently. Oscar von Beringe shot the first mountain gorilla to be discovered and Carl Akeley shot several for the American Museum of Natural History in the early 1920s. Similarly, sports hunters during the 1800s and early 1900s shot western gorillas for skins (Du Chaillu, 1861). Occasionally, gorillas are killed because they have been raiding crops in fields (Hall et al., 1998b) but this is less common than for the other reasons already delineated.

Snares, although not set specifically for gorillas, are known to kill them throughout their range (Hall et al., 1998a; Noss, 1998, 2000) and can be a 
source of high mortality even where protection is supposedly present. Wire and rope snares are set to trap antelope, and animals that get caught struggle to get free, creating deep cuts to their hands or feet. If these cuts become infected the animal can easily die.

Among threats to western lowland gorillas, the bushmeat trade in Central Africa is one of the most serious, and has led IUCN to upgrade the status of western gorillas to endangered. An estimated 1.2 million tonnes of bushmeat are consumed each year in the Congo basin (Wilkie and Carpenter, 1999a), although gorillas form less than $1 \%$ of this trade. In northern Congo, around Motaba River, gorilla and chimpanzee nest densities increase greatly after about $20 \mathrm{~km}$ from villages because of hunting pressures (Kano and Asato, 1994). Around 5\% of the gorilla population has been killed annually. With this rate of offtake, gorilla populations would be expected to decline to 50\% in 10-15 years because of the gorillas' slow reproductive rates (Kano and Asato, 1994); a female gorilla only produces offspring once every three to five years (Watts, 1990). This area has one of the lowest human population densities in Africa apart from the deserts (Cincotta and Engelman, 2000), and yet even here hunting of gorillas is not sustainable. Many studies around the world of traditional hunting of wild animals now show that hunting is rarely sustainable unless the human population density is very low (Robinson and Bennett, 2000).

The logging industry can greatly exacerbate the problem of gorilla-hunting. Timber harvesting opens up access to the forest through the construction of roads and hunting almost always increases as timber companies start to extract the wood. Employees earn enough money on the timber concessions to be able to purchase and eat meat more regularly than they can if unemployed, and hence a market for bushmeat is created on the concessions (Wilkie and Carpenter, 1999a). Logging trucks also transport bushmeat to markets in the cities down roads that have been constructed for the timber industry.

Grauer's gorillas in the east of the Congo Basin do not appear to be eaten as much as they are in the west because of taboos among certain people against eating apes. More recently, however, the taboos in the east have been changing and gorillas are now being eaten more commonly (Hall et al., 1998b). Recently as well, many Grauer's gorillas in the montane sector of Kahuzi-Biega National Park have been killed for meat as a result of civil strife in DRC (G. Debonnet and J. Mankoto, personal communication). Between 1998 and 2000 the population fell from around 250 to 130 individuals ( $\mathrm{O}$. Ilambu, personal communication).

Hunting of mountain gorillas for meat has also occurred, but only rarely. It was thought that many mountain gorillas were killed for food in Zaïre (now DRC) during fighting for independence in the 1960s (Weber and Vedder, 1983). Apart from the mortality linked to armed conflict described below, direct killings of mountain gorillas have been rare in the last 20 years because of 
good protection and reasonable support and funding for national parks. However, indirect killing of mountain gorillas caught in snares set for antelope still occurs.

Finally, the Democratic Republic of Congo is well-known for its mineral wealth and with the onset of civil war many protected areas have been invaded by local villagers in search of gold, diamonds and more recently columbotantalite (Coltan). Coltan is an ore that is used to make semiconductors and is important for electronic components of cell phones and computers. Coltan is found in scattered locations but where it occurs it can be found in fairly large quantities. During 1998-2000 coltan was selling at about $\$ 80 / \mathrm{kg}$ and people were able to mine several kilograms each day creating a huge influx of people into the forests looking for this mineral in a region where monthly salaries on average are less than $\$ 30$. In the Nyungwe Forest in Rwanda, for example, there were three camps of over 3000 miners and only 90 guards to try to evict them. Kahuzi-Biega National Park, which contained about $86 \%$ of Grauer's gorillas in 1996, has been the most severely affected with large mining camps having been established in the lowland sector where coltan can be found. Miners have been hunting large mammals, including gorillas, to feed themselves while they are there, and to date, it has been impossible to reach this part of the park to evaluate the impacts of the mines on the gorilla population. The Wildlife Conservation Society (WCS) was involved with other nongovernmental organizations (NGOs) in publicizing the plight of the Kahuzi-Biega gorilla population following a survey that WCS undertook with the Institut Congolais pour la Conservation de la Nature and the Dian Fossey Gorilla Fund International in July 2000. Pressure has subsequently been put on electronics companies to purchase "gorilla-friendly" coltan. This has occurred to some extent and most companies are buying from Australia now. The price of coltan has fallen to about $\$ 18 / \mathrm{kg}$ and coltan is also being found outside forests in Rwanda, which has relieved some of the pressure on the protected areas in this region, and park staff can now control the miners in Nyungwe Forest. However, if the price should increase again in the future, there will be increased pressure on the protected areas again. Mining is still continuing in Kahuzi-Biega park because the insecurity in the region prevents park guards from accessing the lowland sector of the park and they are unable therefore to prevent it.

\section{Disease transmission}

Gorillas are susceptible to human diseases and many in zoos are vaccinated against common human ailments. With small populations of gorillas, any infectious disease could devastate the population. Diseases transmitted to 
immunologically naïve populations have resulted in massive mortality in other species - up to entire populations (Thorne and Williams, 1988; Macdonald, 1996), and primates are especially vulnerable due to their slow reproductive rates (Young, 1994). Disease and subsequent deaths of habituated mountain gorillas have been caused by respiratory outbreaks and scabies (Hastings et al., 1991; Kalema et al., 1998) and several other pathogens have been identified in the population (Mudakikwa et al., 2001). However, little data are available on the impacts of disease, particularly outside the Virunga population. In the closely related chimpanzee (Pan troglodytes), polio and respiratory diseases have occurred (Goodall, 1986). Recent evidence from Minkebe in northern Gabon indicates that gorillas have died in large numbers and are now very rare when in the 1970s they had been common. What killed them is not known but it is thought to be due to an unknown disease (J. M. Fay, personal communication).

Gorilla ecotourism, which started in Rwanda and Uganda in the 1960s, has increased the potential threat of disease transmission. While most of the international tourists visiting Rwanda are fairly fit, having been inoculated against certain diseases, they may be carrying new viruses for the region such as influenza. It is these illnesses to which the gorillas have never been exposed which are potentially the most dangerous (McNeilage, 1996; Butynski and Kalina, 1998). If poorly controlled, tourism can also lead to increased stress in the animals, which can increase susceptibility to disease (Hudson, 1992; McNeilage, 1996). While this was recognized as a risk at the start of the tourism program in Rwanda, the loss of habitat was considered a far greater threat to the gorillas at the time and the potential benefits of tourism were thought to outweigh the possible negative impacts on the gorillas. The tourism program was implemented with rules in place to regulate tourist visiting times and the number of tourists per group. Strict rules also exist on the behavior of park staff and tourists to try to eliminate the risk of passing on a disease to which the animals will not have been previously exposed (Homsy, 1999). For example, a minimum distance of $5 \mathrm{~m}$ is supposed to be maintained between people and gorillas, eating and drinking are not allowed when with the gorillas, and all human fecal material in the park should be buried. However, some of these rules are not always adhered to (Butynski and Kalina, 1998).

Homsy (1999) points out that many diseases that are dangerous to gorillas can survive in feces in the soil for up to six months or more. These include hepatitis A, poliovirus, tapeworm, and the TB bacillus. Increasing human density as a result of roads being built into the forest and people settling along them will increase the potential for human-gorilla transmission of disease. Gorillas that live near human populations have probably been exposed to human parasites for decades. People visit the forest to collect firewood, building poles, and nontimber forest products, to harvest trees for timber and to hunt, and might 
defecate and urinate while in the forest. Infections transmitted via feces are far more likely to occur than are respiratory diseases, and the risks from such fecal transmission may be at least as serious as those from close proximity of people to gorillas for limited periods of time (Homsy, 1999).

During the war and civil unrest that has occurred during the 1990s in the Congo Basin, people moved into the more remote forests as either refugees or rebel groups that were being chased. They were poorly nourished, living in harsh and unsanitary conditions, and many died in the forests. How these movements might have affected the health of gorilla populations is unknown, but clearly this could greatly increase the threat of disease outbreaks devastating such small populations of gorillas.

\section{War and political unrest}

Civil wars are not a new threat to the conservation of protected areas, but the participants are now much better armed than they were in the past. The ever-shrinking forests that result from expanding human populations are ideal hiding places or retreats for armed opposition groups. Many national parks in Central Africa are associated with the presence of rebels, and conflicts extend over a much larger arena than they used to. These parks include Kahuzi-Biega National Park, Virunga National Park, and Maiko National Park, where most of the populations of eastern gorillas occur. There are hundreds of thousands of refugees throughout the range of G. g. graueri and in areas of G. g. gorilla range in the Democratic Republic of Congo. Protected areas such as the Virungas, which straddle international borders, are particularly at risk as people can move back and forth between countries easily while hiding within the forest. Refugees who fled Rwanda for Zaïre were settled near the Virunga National Park in one of the world's largest refugee camps and ended up deforesting $113 \mathrm{~km}^{2}$ of the park while collecting firewood (Henquin and Blondel, 1996). Similarly, a refugee camp sited near the Kahuzi-Biega National Park increased the price of fuel wood by two to three times, and although the camp and the refugees are now gone, there is still a big fuel-wood problem for the people who live in this region (B.-I. Inogwabini, personal communication). However, in this case the park warden managed to keep the refugees and the fuel-wood collection outside the park.

Little is known about how the recent wars in central Africa have affected gorilla populations. It is known that mountain gorillas around the volcano Mikeno in DRC dropped in number between 1960 and 1971-73 (Weber and Vedder, 1983) and it is thought this may have been due to increased hunting after the civil war in the 1960s. More recently the civil war in Rwanda and DRC 
has made it impossible to assess how the mountain gorillas have fared. It has been possible to monitor the habituated groups of gorillas, however, and most of these have survived remarkably well. It is known that since 1995 at least 18 gorillas have been killed in the Virunga National Park (DRC) as a result of poaching with firearms or getting caught in crossfire. Remarkably, almost all habituated individuals were accounted for in Rwanda in 1999 after 14 months without any monitoring during which many rebels and refugees lived in the park. Recent evidence from known numbers of habituated animals and ranger counts of nest groups indicates that the population has risen to a minimum count of about 360 animals (Kalpers et al., unpublished data).

In Kahuzi-Biega National Park there has been heavy hunting of gorillas for meat in the mountain sector as a result of war and displacement. The gorilla population in that area has been reduced from 250 to 130 individuals. Nobody from the Congolese National Parks has been able to visit the lowland sector where the bulk of the gorilla population was found in the mid 1990s (Hall et al., $1998 b$ ) and we have no idea how they are faring. We only know that there are many people living in the forest mining for gold and diamonds, and probably living off the wild animals in the forest, including gorillas given that taboos have been changing.

\section{Conserving gorilla populations}

Traditional protected areas are still one of the main conservation strategies to address the threats to gorillas, particularly hunting and habitat loss. However, more recently, efforts to protect gorillas outside traditionally protected areas by working with logging companies and other interested groups have met with some success in reducing hunting pressure. Recent experience in areas of conflict has shown that all is not necessarily lost when war breaks out. In this section we describe how different conservation strategies, both new and traditional, are contributing to the future conservation of gorillas.

\section{Protected areas}

The first national park in Africa, the Virunga Park, was created in 1925 to protect the mountain gorilla. This park still exists today but in a highly degraded state as a result of human population growth and civil wars in this part of Africa. While the gorillas and the montane habitat are thought to be relatively intact, the lowland savanna parts of the park have been severely hunted and most large mammal populations have been greatly reduced. Many of the parks in eastern DRC have only been "paper parks" in that they have often had very little 
resources flowing to them to help the park staff maintain them. While paper parks may not be effective, well-funded, managed parks, they have historically fared better than areas that had no protected status, and people have often respected their boundaries (Hart and Hall, 1996; Oates, 1999). Most of the resources that have reached many parks have come from international NGOs. This is a criticism of most of the protected areas in the Congo Basin, whose governments have not put much revenue into supporting them. Analyses of the possibility of generating revenue from tourist receipts (Wilkie and Carpenter, $1999 b$ ) show that it is highly unlikely that the costs of managing the protected areas in the Congo Basin can be generated in this way. Mountain gorillas, living in a small island of habitat that is easily accessed by tourists and can be intensively protected by a relatively small number of rangers, may be able to survive through the support of tourism dollars. However, it is unlikely that tourism will be able to support the conservation of eastern and western lowland gorillas in the long term, as they live over a much wider range, many in areas difficult to access.

If gorillas are to be conserved into the next millennium, national parks are going to be essential tools for maintaining viable populations. Only parks of sufficiently large size will be able to maintain ecologically functional populations of gorillas, and given the typical densities at which gorillas are found (Table 17.1) this will generally mean at least several hundred square kilometers. The international community is going to have to support conservation efforts for this species. Through treaties, such as the 1993 Rio Convention on Biological Diversity, the developed world has committed to support conservation in the southern hemisphere countries, which hold most of the world's biodiversity. Recently one important precedent was set in this regard. In recognition of the plight of the five World Heritage Sites in DRC, the UN Foundation promised \$3 million to support these protected areas (Salonga, Kahuzi-Biega, Okapi, Virunga, and Garamba) through an emergency relief fund. This precedent will hopefully lead to further support of other areas considered to be of global importance in the future, particularly during periods of conflict. There is also a move to try to establish a trust fund to support the protected areas in the Congo Basin known as the Central Africa Management of Biodiversity project (CAMBIO). The World Bank is being approached to provide approximately $\$ 90$ million to establish this fund. Whether this crucial initiative will succeed or fail will depend on the popular support it receives. Another small endowment trust fund has already been set up to support conservation efforts in and around Bwindi and Mgahinga, two forests in southwest Uganda where mountain gorillas are found. The Mgahinga and Bwindi-Impenetrable Forest Conservation Trust was set up in 1995 with initial funds from the Global Environment Facility, and further support from the United States Agency for International Development and the Netherlands government, and provides a sustainable source of funding for 
park management, research, and community conservation projects. Eventually it is hoped that this trust will reach $\$ 10$ million or more, at which point it should generate around $7 \%$ or $\$ 700000$ per year to fund its programs.

\section{Working with logging companies}

Protected areas alone may not be enough to conserve healthy populations of gorillas. If gorillas are also going to survive outside protected areas then something must be done to curb the hunting. In all countries of the Congo Basin the hunting of gorillas is illegal but this does not stop the trade in gorilla meat. There are little or no resources to monitor and police this illegal hunting. The best places to target actions to conserve gorillas outside protected areas are in large areas of land controlled by one or a few people, where such individuals have control over what can happen on their land. Working with logging companies to conserve gorillas outside protected areas would ensure that the populations are not isolated and this may be vital if changes in the forest extent occur as a result of global warming. Logging companies are an obvious choice in this respect because they usually have access to large concessions that can be held for many years. Some of the key concessions neighbor important protected areas. Often there are few roads that enter or exit the concession so that these points can be monitored and the bushmeat trade controlled to some extent. Traditionally, conservationists have been at odds with timber extraction companies, but realistically we are unlikely to be able to raise sufficient funds to offset the opportunity costs of logging in the Congo Basin. If conservationists and timber companies can learn to collaborate then we are more likely to succeed at saving these animals over large areas of forest.

The Wildlife Conservation Society has been piloting a project that is a collaborative effort between the Ministry of Forest Economy in the Congo and the Congolaise Industrielle des Bois (CIB), a logging company. The project operates around the periphery of the Nouabalé-Ndoki National Park in northeast Congo and has been working with the company to establish mutually agreed upon guidelines for hunting, which include a ban on the hunting of apes, elephants and other endangered/vulnerable species and a ban on the export of meat from the concession. Commercial bushmeat hunting has reduced as a result through enforcement by the local community, the logging company, and the WCS project. The incidence of gorilla and chimpanzee hunting has dropped by an estimated $90 \%$ on this concession in the last two years (Elkan, 1999) and recently an employee of CIB lost his job for killing a gorilla. In addition, the company gave up a large part of its concession in an area where there are apes with little fear of humans, presumably because they have never come in 
contact with them. The World Bank has become interested in promoting this pilot project in other concessions in Central Africa and has been bringing together the chief executive officers of many of the companies operating in this region to encourage them to follow CIB's lead.

\section{Conservation in areas of conflict}

War and political insecurity usually lead to the reduction or complete elimination of bilateral support. Much of the money for international conservation comes from bilateral grants and these funds are usually frozen at the smallest sign of insecurity. This action often has led to the complete cessation of projects that were being supported and the consequent loss of project staff. Experience from WCS's projects in Central Africa has shown that maintaining a presence during war at projects they have supported prior to insecurity has enabled staff to continue some actions on the ground (Plumptre et al., in press). More importantly, they have also been able to negotiate with any changed leadership to ensure that protected areas continue to be recognized ( Fimbel and Fimbel, 1997; Hart and Hart, 1997; Plumptre and Williamson, 2001). Unfortunately, donors tend to withdraw funding at the first sign of instability. Bilateral agencies should consider channeling funds through international NGOs during periods of insecurity if they cannot work directly with governments for political reasons. An analysis of protected areas in Rwanda showed that during the last decade of the twentieth century, only in those protected areas where an NGO presence was maintained did the protected area survive (Plumptre et al., in press).

\section{Conclusions}

The future of the gorilla in the long term is still not secure despite the fact that the first park to protect this species was created over 75 years ago. It is inevitable that the global population of Gorilla will be reduced as the human population continues to increase, along with the consequent threats to gorillas, particularly in central Africa where many gorillas still exist outside protected areas. Even those within protected areas are not secure as many of the parks and reserves with gorillas lack adequate financial and institutional support to combat the recent increase in the hunting of animals for bushmeat. If the gorilla is to survive another century, individuals and institutions within the richer countries of the world will have to be prepared to provide financial support for their protection for many years to come.

However, not everything is bleak. Apes are highly charismatic species and the tourism programs in the eastern part of the gorilla's range show that people 
are willing to pay large sums of money to be able to visit them in the wild. Through television and books, the image of gorillas has been transformed from aggressive brutes in the nineteenth century to the "gentle giants" we know them to be at the beginning of the twenty-first century. Raising funds for gorillas is generally much easier than for many other species and the recent creation of a Great Ape Fund in the U.S.A. by Congress has ensured a certain level of support to all apes for the foreseeable future. More difficult will be to try and ensure the long-term survival of all the genetic and ecological variation within this genus, particularly the smallest populations of the most endangered subspecies. There have been recent proposals to raise the international status of apes, given their genetic and behavioral similarities to humans, possibly creating "World Heritage Species" to complement World Heritage Sites (International Primatological Society, personal communication). This would certainly benefit these charismatic animals and could raise their profile considerably. Gorillas can act as very useful "umbrella species" where they occur, so that highlighting the need for their conservation can lead to the protection of many other rainforest species. Raising their profile and ensuring their long-term protection would therefore conserve much of the other biodiversity found in the forests where they live.

\section{References}

Barnes, R.F.W. (1990). Deforestation trends in tropical Africa. African Journal of Ecology, 28, 161-173

Butynski, T.M. and Kalina, J. (1998). Gorilla tourism: A critical look. In Conservation of Biological Resources, eds. E.J. Milner-Gulland \& R. Mace, pp. 280-300. Oxford, U.K.: Blackwell Scientific Publications.

Butynski, T.M. and Sarmiento, E. (1995). Gorilla census on Mt Tshiaberimu: Preliminary report. Gorilla Journal, 1, 11.

Carroll, R. (1988). Relative density, range extension, and conservation potential of the lowland gorilla (Gorilla gorilla gorilla) in the Dzanga-Sangha region of southwest Central African Republic. Mammalia, 52, 309-323.

Cincotta, R.P. and Engelman, R. (2000). Nature's Place: Human Population and the Future of Biological Diversity. Washington, D.C.: Population Action International.

Du Chaillu, P.B. (1861). Explorations and Adventures in Equatorial Africa. New York: Harper.

Elkan, P. (1999). Wildlife management in areas surrounding Nouabalé-Ndoki National Park. Gnusletter, 18(2), 15-16.

Fay, J.M. (1989). Partial completion of a census of the lowland gorilla (Gorilla g. gorilla (Savage and Wyman)) in southwestern Central African Republic. Mammalia, 53, 203-215.

Fay, J.M. (1997). The ecology, social organisation, populations, habitat and history of the western lowland gorilla (Gorilla g. gorilla Savage and Wyman, 1847). PhD thesis, Washington University, St. Louis, MO. 
Fimbel, C. and Fimbel, R. (1997). Conservation and civil strife: Two perspectives from Central Africa: Rwanda: The role of local participation. Conservation Biology, 11, 309-310.

Fossey, D. (1983). Gorillas in the Mist. Boston, MA: Houghton Mifflin.

Goodall, J. (1986). The Chimpanzees of Gombe: Patterns of Behavior. Cambridge, MA: Harvard University Press.

Groves, C.P. (1967). Ecology and taxonomy of the gorilla. Nature, 213, 890-893.

Groves, C.P. (2001). Primate Taxonomy. Washington, D.C.: Smithsonian Institution Press.

Hall, J.S., White, L.J.T., Inogwabini, B.-I., Omari, I., Morland, H.S., Williamson, E.A., Saltonstall, K., Walsh, P., Sikubwabo, C., Bonny, D., Kiswele, K.P., Vedder, A., and Freeman, K. (1998a). Survey of Grauer's gorillas (Gorilla gorilla graueri) and eastern chimpanzees (Pan troglodytes schweinfurthii) in the Kahuzi-Biega National Park lowland sector and adjacent forest in eastern Democratic Republic of Congo. International Journal of Primatology, 19, 207-235.

Hall, J.S., Saltonstall, K., Inogwabini, B-I., and Omari, I. (1998b) Distribution, abundance and conservation status of Grauer's gorilla. Oryx, 32, 122-130.

Harcourt, A.H. (1981). Can Uganda's gorillas survive? A survey of the Bwindi Forest Reserve. Biological Conservation, 19, 262-282.

Harcourt, A.H. (1996). Is the gorilla a threatened species? How should we judge? Biological Conservation, 75, 165-176.

Harcourt, A.H. and Fossey, D. (1981). The Virunga gorillas: Decline of an island population. African Journal of Ecology, 19, 83-97.

Harcourt, A.H., Stewart, K.J., and Inahoro, I.M. (1989). Nigeria's gorillas: A survey and recommendations. Primate Conservation, 10, 73-76.

Hart, J.A. and Hall, J.S. (1996). Status of eastern Zaïre's forest parks and reserves. Conservation Biology, 10, 316-324.

Hart, T. \& Hart, J. (1997). Conservation and civil strife: Two perspectives from Central Africa: Zaïre: New models for an emerging state. Conservation Biology, 11, 308-309.

Hastings, B.E., Kenny, D., Lowenstine, L.J., and Foster, J.W. (1991). Mountain gorillas and measles: Ontogeny of a wildlife vaccination program. American Association of Zoological Veterinarians Annual Proceedings, 1991, 198-205.

Henquin, B. and Blondel, N. (1996). Etude par télédetection sur l'évolution recente de la couverture boisée du Parc National des Virunga. Unpublished report, Laboratoire d'Hydrologie et de Télédetection, Gembloux, Belgium.

Homsy, J. (1999). Ape Tourism and Human Diseases: How Close Should We Get? Report to the International Gorilla Conservation Program, Kigali.

Hudson, H.R. (1992). The relationship between stress and disease in orphan gorillas and its significance for gorilla tourism. Gorilla Conservation News, 6, 8-10.

IUCN (2000). Red List of Threatened Species. Gland, Switzerland: IUCN. http://www.redlist.org/

Jones, C. and Sabater Pi, J. (1971). Comparative ecology of Gorilla gorilla (Savage and Wyman) and Pan troglodytes (Blumenbach) in Rio Muni, West Africa. Biblioteca Primatologica, 13, 1-96.

Kalema, G., Kock, R.A., and Macfie, E. (1998). An outbreak of sarcoptic mange in free-ranging mountain gorillas (Gorilla gorilla beringei) in Bwindi Impenetrable 
National Park, Southwestern Uganda. In Joint Proceedings of the AAZV and AAWV Annual Meeting, Omaha, Nebraska, p. 438 (abstract).

Kano, T. and Asato, R. (1994). Hunting pressure on chimpanzees and gorillas in the Motaba River area, Northeastern Congo. African Study Monographs, 15, 143-162. Lahm, S.A. (1994). Hunting and Wildlife in Northeastern Gabon: Why Conservation Should Extend beyond Protected Areas. Report to Institut de Recherche en Ecologie Tropicale, Makoukou, Gabon.

Macdonald, D.W. (1996). Dangerous liaisons and disease. Nature, 379, 400-401.

McNeilage, A. (1996). Ecotourism and mountain gorillas in the Virungas. In The Exploitation of Mammal Populations, eds. V.J. Taylor and N. Dunstone, pp. 334-344. London: Chapman \& Hall.

McNeilage, A., Plumptre, A.J., Brock-Doyle, A., and Vedder, A. (1998). BwindiImpenetrable National Park, Uganda Gorilla and Large Mammal Census, 1997. WCS Working Paper no 14. Washington, D.C.: Wildlife Conservation Society.

Mudakikwa, A.B., Cranfield, M.R., Sleeman, J.M., and Eilenberger, U. (2001) Clinical medicine, preventative health care and research on mountain gorillas in the Virunga Volcanoes region. In Mountain Gorillas: Three Decades of Research at Karisoke, eds. M.M. Robbins, P. Sicotte and K.J. Stewart, pp. 341-360. Cambridge, U.K.: Cambridge University Press.

Mwanza, N., Maruhashi, T., Yumoto, T., and Yamagiwa, J. (1988). Conservation of eastern lowland gorillas in the Masisi region, Zaïre. Primate Conservation, 9, 111-114.

Noss, A.J. (1998). Cables, snares and bushmeat markets in a central African forest. Environmental Conservation, 25, 228-233.

Noss, A.J. (2000). Cables, snares and nets in the Central African Republic. In Hunting for Sustainability in Tropical Forests, eds. J.G. Robinson and E.L. Bennett, pp. 282 304. New York: Columbia University Press.

Oates, J.F. (1996). African Primates: Status Survey and Conservation Action Plan. Gland, Switzerland: International Union for Conservation of Nature and Natural Resources.

Oates, J.F. (1999). Myth and Reality in The Rainforest: How Conservation Strategies Are Failing in West Africa. Berkeley, CA: University of California Press.

Plumptre, A.J. and Williamson, E.A. (2001). Conservation-oriented research in the Virunga region. In Mountain Gorillas: Three Decades of Research at Karisoke, eds. M.M. Robbins, P. Sicotte, and K.J. Stewart, pp. 361-389. Cambridge, U.K.: Cambridge University Press.

Plumptre, A.J., Masozera, M., and Vedder, A. (2001). The Impact of Civil War on the Conservation of Protected Areas in Rwanda. Washington, D.C.: Biodiversity Support Program.

Robinson, J.G. and Bennett, E.L. (eds.) (2000). Hunting for Sustainability in Tropical Forests. New York: Columbia University Press.

Sarmiento, E.E. and Oates, J.F. (2000). The Cross River gorillas: A distinct subspecies, Gorilla gorilla diehli Matschie 1904. American Museum Novitates, 3304, 1-55.

Sarmiento, E.E., Butynski, T.M., and Kalina, J. (1996). Gorillas of Bwindi-Impenetrable Forest and the Virunga Volcanoes: Taxonomic implications of morphological and ecological differences. American Journal of Primatology, 40, 1-21. 
Schaller, G.B. (1963). The Mountain Gorilla: Ecology and Behavior. Chicago, IL: University of Chicago Press.

Stromayer, K. and Ekobo, A. (1991). Biological Surveys of Southeastern Cameroon. Report to European Community, Brussels.

Thorne, E.T. and Williams, E.S. (1988). Disease and endangered species: The blackfooted ferret as a recent example. Conservation Biology, 2, 66-74.

Tutin, C.E.G. and Fernandez, M. (1984). Nationwide census of gorilla (Gorilla g. gorilla) and chimpanzee (Pan t. troglodytes) populations in Gabon. American Journal of Primatology, 6, 313-336.

Watts, D.P. (1990). Mountain gorilla life histories, reproductive competition and sociosexual behavior and some implications for captive husbandry. Zoo Biology, 9, 185-200.

Weber, A.W. (1987). Ruhengeri and its resources: An environmental profile of the Ruhengeri Prefecture. Kigali: ETMA/USAID.

Weber, A.W. and Vedder, A.L. (1983). Population dynamics of the Virunga gorillas 1959-1978. Biological Conservation, 26, 341-366.

White, L.J.T. (1992). Vegetation history and logging disturbance: Effects on rainforest mammals in the Lopé Reserve, Gabon (with special emphasis on elephants and apes). $\mathrm{PhD}$ thesis, University of Edinburgh, Edinburgh, U.K.

White, L.J.T. (1994). Biomass of rainforest mammals in the Lopé Reserve, Gabon. Journal of Animal Ecology, 63, 499-512.

Wilkie, D.S. and Carpenter, J. (1999a). The impact of bushmeat hunting on forest fauna and local economies in the Congo Basin: A review of the literature. Biodiversity and Conservation, 8, 927-955.

Wilkie, D.S. and Carpenter, J. (1999b). Can nature tourism help finance protected areas in the Congo Basin? Oryx, 33, 332-338.

Williamson, L. and Usongo, L. (1995). Survey of Elephants, Gorillas and Chimpanzees, Reserve de Faune de Dja, Cameroun. Report to ECOFAC Composante Cameroun and Ministère de l'Environment, Cameroun.

World Resources Institute (2000a). A First Look at Logging in Gabon. Washington, D.C.: World Resources Institute.

World Resources Institute (2000b). An Overview of Logging in Cameroon. Washington, D.C.: World Resources Institute.

Young, T.P. (1994). Natural die-offs of large mammals: Implications for conservation. Conservation Biology, 8, 410-418. 